\title{
Breast cancer discovery sparks new debate on patenting human genes
}

Paris, Houston and London. The patenting of a gene for breast cancer susceptibility, whose discovery was announced last week by the US biotechnology company Myriad Genetics (see pages 270 and 279) has reopened the debate about how best to commercialize results from the human genome project - and whether patents should be granted on individual genes.

Mark Skolnick, from the University of Utah in Salt Lake City, headed the team which won the race to isolate the gene $B R C A 1$, whose approximate location was first identified in 1990 by Mary-Claire King, a geneticist at The University of California at Berkeley. (The baton immediately passed to runners racing to isolate a second breast cancer gene, BRCA2, just localized by a team headed by UK researchers; Science will publish the papers on 7 October and 30 September, respectively.)

Some genome researchers are anxious, however, about the decision of Myriad Genetics, a company cofounded by Skolnick in 1991 (see below), to patent BRCA1. King, who describes Skolnick's isolation of $B R C A 1$ as "a lovely piece of work", attributes these worries to the fact that $B R C A 1$ is the first gene of potentially great importance for testing large numbers of people.

Despite the passions it has aroused, the patenting of $B R C A 1$ may help to clarify the debate about whether human genes should be patented. This was sidetracked in 1991 by the bid - later withdrawn - by the US National Institutes of Health $(\mathrm{NIH})$ to patent thousands of cDNA fragments.

The arguments in the Venter case centred on whether gene fragments whose function was unknown could be patented, and on whether NIH should potentially gain control over hundreds of products to which it had contributed little. In contrast, there is an emerging consensus that current patent law allows genes whose function are known such as those for human interferon and relaxin - to be patented.

But the ethical debate continues. Noëlle Lenoir, president of the international bioethics committee set up last year by the United Nations Educational Scientific and Cultural Organization, says the committee has not yet taken a position on patenting genes.

But she says she believes it would fall outside the remit of her committee, which is mainly concerned with human rights issues raised by the human genome project. Patenting genes, she says, could be more a

\section{a hunt for genes}

Houston. Myriad Genetics Inc was founded in 1991 jointly by Mark H. Skolnick, professor of medical informatics at the University of Utah, and Walter Gilbert of Harvard University, the Nobel prizewinner who also helped to found Biogen, one of the first major biotechnology companies, in 1978.

Skolnick, who is vice-president of research at Myriad, says his time is split equally between Myriad and the university. He says that he formed the company, which is privately held with headquarters in Salt Lake City, Utah, because the university was not in a position to provide either the full scientific or financial resources needed to pursue "the common genes".

Myriad's initial plans are to focus on discovering genes linked to diseases such as cancer of the breast, colon, lung, and prostate, and heart disease. It is already pursuing the BRCA2 gene, whose approximate location was also announced last week (the British researchers involved in the discovery say that, after the controversy surrounding patent rights, they have dropped plans to collaborate with Myriad on this project).

Two and a half years ago, Myriad agreed a worldwide exclusive licence to the gene with the University of Utah. The company subsequently entered into sublicensing agreements with Eli Lilly \& Co. of Indianapolis and Hybritech of San Diego, Lilly's wholly owned subsidiary. In return, both companies provided it with financial backing. With the BRCA1 gene now identified, Myriad plans to collaborate with Lilly in developing new therapeutic agents for treating breast cancer and with Hybritech to develop diagnostic kits.

Part of Myriad's corporate strategy, as outlined in a company document, is that it plans to file 'composition of matter' patents on any genes discovered, and on the products (proteins) and mutations of those genes. It also plans to seek 'method of use' patents for the diagnostic or therapeutic use of those genes.

Meanwhile, in another illustration of the increasing interest of genetic engineering companies in genome technologies, Genentech announced last week that it has made an investment in Sequana Therapeutics of San Diego, California, in exchange for an undisclosed amount of equity. The relationship gives Genentech the rights to negotiate for licenses to those of Sequana's discoveries which its main research sponsors decide not to take up, D. G.

\author{
IMAGE \\ UNAVAILABLE \\ FOR COPYRIGHT \\ REASONS
}

\section{'Molecular mammography' will soon complement traditional screening.}

question of scientific ethics than bioethics.

From one point of view, patenting human genes has less to do with patent law (or bioethics) than with whether it will encourage or hinder investment, and thus progress, in gene-based technologies. Public resistance to patenting genes also remains strong. But some dismiss this as emotional, pointing out that DNA sequences are molecules, like any other patentable chemical structure.

Nevertheless, as last week's announcement has revealed, many in the research community remain uncomfortable about patenting genes. Much of this discomfort stems from their belief that the human genome project should be a cooperative search for new knowledge, rather than a self-interested search for profits.

Mike Stratton one of the scientists from the Institute for Cancer Research in London who have localized the $B R C A 2$ gene, points out that all potentially useful genes are having patents taken out on them. "Many clinical geneticists are uncertain how positive it will be for the people concerned."

The recent explosion of commercial genome companies is already leading to demands for greater intellectual property protection as private funding outstrips the relatively small amount of state funding for genome research. Myriad - and others, such as Millennium (see Nature 368, 175; 1994) - point out that companies need returns on the massive investments needed to pay for heavy development costs, in particular to close the 'therapeutic gap' between the availability of diagnostics and subsequent therapeutics.

Stephen Friend, a researcher at the Cancer Center at Massachusetts General Hospital, says the isolation of the $B R C A l$ gene "feels like a new era in terms of the power of industrial support, providing the opportunity that allowed a superb set of experiments to proceed very quickly." 
Stratton also acknowledges that "it's a new ball-game", pointing out that the companies set up to hunt for new genes "have budgets with an extra zero on the end compared to those of most academic groups".

Some researchers argue that patenting genes will slow down scientific progress, and that those seeking patent protection will delay publication. But others argue that communication could be eased by faster patenting procedures.

Skolnick hopes people will not prejudge Myriad on its licensing policy. "We want to collaborate, and we're not going to slit our throats by cutting everybody off or by charging exorbitant amounts," he says. "As we develop a policy, I'm sure we'll test the waters, and if we get whacked good and hard then we'll hopefully refine the policy."

But it is in the European Union (EU) that the outlook for gene patents remains cloudiest. The European Parliament is opposing parts of a European Commission directive that would standardize national laws on patenting life. In its current draft form, the directive rules that parts of the human body, including genes, cannot be patented when they remain in the body.

After the Council of Ministers decided this week not to accept amendments proposed by the parliament, representatives of the two sides will now have to meet to try to agree a single text. But, rather than adopt a directive that explicitly banned patenting genes, ministers could well abandon the whole draft.

Declan Butler \& Diane Gershon

\section{Court rules cell lines are protected by law}

Washington. In a precedent-setting decision, a court in Baltimore, Maryland, has required a researcher at the National Institutes of Health (NIH) in Bethesda, Maryland, to pay $\$ 5,000$ for deliberately destroying a cell line developed by co-workers in his laboratory.

After a five-day trial, Judge Peter Messitte ruled that Prince Kumar Arora, a researcher in the NIH's Laboratory of Neuroscience, destroyed cells developed by a colleague, Yochitatsu Sei, as part of an investigation of the impact of certain molecules on the brain.

Imposing both compensatory damages of $\$ 400$ and punitive damages of $\$ 5,000$, the court concluded that Arora had been motivated by jealousy. The ruling effectively enlarges the concept of 'conversion of property' to give protection to genetically engineered cell lines developed during the course of a research project.

The NIH, which participated as a civil party in the suit, had asked the court to accept the idea of 'conversion', reserved until now for circumstances in which one individual illegally appropriates the proceeds of property belonging to another. $\square$

\section{EPA rebuffs challenge to its assessment of dioxin data}

Washington. With its latest study of health risks from dioxins nearly complete, the US Environmental Protection Agency (EPA) last week went out on a limb to say that dioxins probably cause cancer in humans. But the agency says it still needs additional data before making this conclusion definitive; and the case may never be closed entirely.

EPA has released a "public review draft" of its three-year reassessment of dioxin risks, the most exhaustive scientific review of any family of compounds ever undertaken by the agency. As expected, the agency is sticking with its 1985 assessment that dioxins are a proven animal carcinogen and a likely human carcinogen, even in trace amounts.

In addition, the EPA draft says that dioxins may have other effects on health, including reproductive problems and suppression of the immune system, although it is not yet clear at what dosage those effects occur in humans.

The report will not be finalized until September 1995, following a four-month public comment period, and a review by EPA's Science Advisory Board early next year. Meanwhile, the agency is calling for additional data from scientists, industry, government agencies and any other groups that might have new information on dioxin.

The draft report points out that there are large gaps in researchers' understanding of dioxin sources and the levels at which it exists in the environment and in food, the principal route of human exposure. EPA estimates that 95 per cent of dioxins come from incinerators that burn medical and municipal waste, but says there may also be unknown sources.

EPA initiated the reassessment in 1991, after some scientists had begun to question whether the risks from dioxin had been overstated. Research showing that TCDD, the most toxic of the dioxins, had first to bind with a receptor protein before causing any harm to cells implied that there might be a threshold before the binding occurred below which dioxin was not a problem.

EPA's models assume there is no such threshold, and therefore no 'safe' level of dioxin. Most European countries, as well as Canada, think this model is unrealistic, and have set their dioxin exposure limits much higher. But, after three years of reviewing the data, and conducting dose-response studies in its own laboratories and others, EPA still has not identified a threshold amount of dioxin that triggers a response.

Other incriminating studies were published during the three-year reassessment, including stronger epidemiological data link- ing dioxin exposure to excessive cancer cases in Seveso, Italy, the site of an explosion in 1976 at a chemical plant. Other recent research has tied dioxin to endometriosis in rhesus monkeys and the suppression of the immune system in mice.

Much of the work for EPA has been spent staying abreast of these new findings. Lynn Goldman, the agency's assistant administrator for pesticides and toxics, says, "Every week there are new studies that are published. It's a challenge to keep up with the data."

Mindful of past criticism of its risk analysis methods, EPA has gone to great lengths during the dioxin reassessment to include participation of external scientists. Earlier drafts of the study went through three separate peer reviews, as well as a review by scientists in other federal agencies.

The authors or co-authors of several chapters were in fact scientists outside EPA. "This has been a new approach for the agency, to really make this an inclusive process," says Linda Birnbaum, director of the agency's Environmental Toxicology Division in Research Triangle Park, North Carolina.

Birnbaum says that providing definitive proof that dioxin causes cancer in humans could be a very tough proposition. "We need unequivocal human data, and that's very difficult to get."

One of the problems with dioxin epidemiology, says Birnbaum, is that these chemicals do not cause a unique kind of tumour that is readily identifiable. As a result, dioxin effects would not stand out from those of any other carcinogen. "We're looking at relatively small incidences over very large background incidences," she says.

Despite its contention that even minute amounts of dioxin pose a health risk, EPA is keen to avoid appearing alarmist. There is relatively little dioxin in the environment only 30 pounds in the entire United States, by one estimate. As a result, says Goldman, even though dioxins accumulate in fatty tissue and show up in beef, dairy products and fish, the amounts are so small that the benefits of a healthy diet far outweigh the risks from dioxin.

Indeed, EPA says it will not take any new regulatory action until the results of the reassessment have been finalized next year. Considering that it has already proposed new rules cutting dioxin emissions from pulp and paper mills and municipal waste incinerators, and that it expects to propose new rules on medical waste incinerators next February, there may not be much dioxin around by the time the last bit of scientific evidence is in.
Tony Reichhardt 